\title{
ЗАБЕЗПЕЧЕННЯ КОНКУРЕНТОСПРОМОЖНОСТІ ЗАКЛАДУ ВИЩОЇ ОСВІТИ В КОНТЕКСТІ СОЦІАЛЬНОЇ ВІДПОВІДАЛЬНОСТІ
}

\author{
Кирчата І.М., канд. екон. наук, доцент \\ Шериенюк О.М., канд. екон. наук, доцент \\ Харківський національний автомобільно-дорожній університет
}

Постановка проблеми. Інтеграція української освіти в глобальний економічний простір сьогодні вже є об'єктивною тенденцією розвитку та передбачає відповідність закладів освітньої діяльності міжнародним вимогам, стандартам. Сучасна дійсність внесла корективи в розуміння соціальної відповідальності, чим в значній мірі по-новому поставила проблему підвищення рівня їх конкурентоспроможності, яка раніше розглядалася переважно як сукупність фінансових результатів.

Перед системою освіти сучасної України, особливо вищої, постає відповідальна задача - виховати в країні сучасне покоління фахівців економічно грамотних, здатних і готових проявляти креативні підприємницькі здібності, успішно розвивати економіку, в цивілізованій формі та проявах регулювати ринкові відносини.

Ринок освітніх послуг, маючи характерні відмінності від інших видів ринку послуг, що проявляються в особливостях змісту, технологій i умов їх реалізації, має забезпечувати набуття такого рівня професійних компетенцій, який би задовольнив всі зацікавлені сторони (виробники, продавці, прямі та непрямі споживачі освітніх послуг, посередники).

Загострення глобальної конкуренції вимагає вдосконалювати існуючі форми соціально-економічних відносин, щоденно використовувати нові ефективні інструменти управління та розробляти нові механізми взаємовідносин «освіта-бізнес-суспільство».

Процес формування конкурентних переваг потребує нового інструментарію 3 «соціально-орієнтованою компонентою», який би інтенсифікував партнерські відносини між освітою, суспільством і бізнесом.

Аналіз останніх досліджень і публікацій. Сучасний менеджмент виокремлює соціальну відповідальність як один 3 інструментів, основні принципи якого визначають обов'язковою участь бізнес-представників та освіти в розвитку суспільства, а в зону відповідальності потрапляють фактори неекономічного характеру, які фокусуються на аспекті соціальної значущості [1-8].

Серед безлічі дефініцій соціальної відповідальності загальноприйнятим вважається визначення, яке дає Міжнародний стандарт ISO 26000 «Керівництво 3 соціальної відповідальності» (2010р.). Соціальна відповідальність представляється як «відповідальність організації за вплив своїх рішень та діяльності на суспільство і навколишнє середовище через прозору і етичну поведінку, яка: сприяє сталому розвитку, включаючи здоров'я i добробут 
суспільства; враховує очікування зацікавлених сторін; відповідає законодавству та узгоджена з міжнародними нормами поведінки» [9].

У наукових публікаціях висвітлюються проблеми розвитку вищої освіти як складової частини загальної системи освіти у XXI столітті: надлишок обсягу пропозиції на ринку послуг вищої освіти; інтернаціоналізація; фінансова криза університетської освіти та пошук шляхів виходу 3 неї; диверсифікація вищих навчальних закладів; наявність проблем у системі забезпечення якості вищої освіти; новітні технології навчання і проблема відкритості та конкурентоспроможності університетів; вирівнювання національних освітніх систем i роль університету в цьому процесі; удосконалення управління; соціальна відповідальність університетів [10].

Під соціальною відповідальністю вищої освіти розуміється відповідальність вищих навчальних закладів, зокрема, університетів як соціального інституту перед суспільством за результати й якість своєї професійної діяльності [11].

За таких умов вищі навчальні заклади мають нести соціальну відповідальність за ефективне використання [12]:

- суспільних (державних) ресурсів 3 метою підвищення ефективності роботи ВНЗ, забезпечення єдності навчання та виховання, залучення студентів $\mathrm{i}$ викладачів у різні соціальні практики (їх суспільну відповідальність);

- власних ресурсів - для розвитку та консолідації суспільства, проведення демократичних реформ;

- взаємодії 3 окремими громадянами, органами влади, бізнесструктурами, різними організаціями та установами - для функціонування ВНЗ як соціального інституту відкритого типу, центру соціальної політики в регіоні його присутності.

Невирішені складові загальної проблеми. Сьогодні соціальна відповідальність в своій еволюції пройшла ряд етапів розвитку та постала інноваційним вектором на шляху повної інтеграції соціальної відповідальності з системою вищої освіти та діяльністю господарських суб’ єктів.

Динамічні ринкові відносини вимагають від сучасної освітньої системи відповідної роботи з підготовки та виховання соціально орієнтованої ділової особи - особистості з розвиненим культурно-етичним, креативним творчим $\mathrm{i}$ прогресивним економічним мисленням. Поняття «соціально орієнтована ділова особа» виступає при цьому як перспективна модель готовності людини до нового типу професіонально-трудової, підприємницької та соціальноекономічної діяльності в умовах ринку.

Проте вирішення цієї важливої задачі істотно ускладняється відсутністю достатнього практичного досвіду, а також наукової обгрунтованості змісту відповідної підготовки майбутніх фахівців, які відповідали б сучасним вимогам суспільного виробництва та соціальної свідомості.

Формулювання цілей статті. Метою статті $є$ дослідження сутності, визначення концептуального змісту й обгрунтування необхідності впровадження соціальної відповідальності в систему освітньої діяльності як 
необхідної передумови забезпечення іiі конкурентної стійкості в глобальному освітньому просторі, що грунтується на набутті здобувачами вищої освіти високого рівня не лише традиційних професійних компетенцій (навчальна i дослідницька компонента), але й інноваційно орієнтованих і особливих підприємницьких здібностей.

Викладення основного матеріалу дослідження. Соціальна відповідальність передбачає необхідність розробки сучасної концепції, яка заохочувала $б$ усіх учасників взаємовідносин «освіта-бізнес-суспільство» враховувати спільні інтереси, беручи на себе відповідальність за результати своєї діяльності, а також сприяла б гармонійному співіснуванню та налагодженому діалогу між учасниками, приймаючи участь у вирішенні найгостріших соціальних проблем.

Важливого значення набуває не тільки здатність генерувати нові ідеї та приймати креативні рішення, але й психологічна стійкість, що передбачає вміння налагоджувати міжособистісні стосунки без шкоди для основного виду діяльності. Тобто сьогодні навчальний заклад має забезпечувати підготовку фахівців на основі розкриття здібностей до самостійної роботи, що мають оволодіти прекрасними діловими якостями для управлінської діяльності на базі отриманих професійних знань [13].

Зараз наявні передумови для співпраці всіх зацікавлених сторін ринку освітніх послуг, а також для модернізації сфери національної освіти задля подальшого формування новітніх державних освітніх стандартів і професійних компетенцій випускників. Разом з тим, співпраця зацікавлених сторін ринку освітніх послуг не виключає суперництва. Навпаки, конкурентне середовище ускладнюється, оскільки на ринку взаємодіє одночасно велика кількість споживачів освітніх послуг, платників за освітні послуги, роботодавців (непрямі користувачі результатів освітньої діяльності), установ і працівників сфери освітніх послуг, компаній (наприклад, IT-компанії, видавництва, виробники контенту та технологій тощо), держава.

Сучасні реалії вимагають посилення інтеграції науки, освіти й інноваційної діяльності з метою системного впровадження досягнень науки в промисловість, як вагому складову реального сектору економіки, тим самим активізуючи інноваційну діяльність самих підприємств і підсилюючи значущість вищої школи.

Заклад вищої освіти як учасник інтегрованої взаємодії має потенційні можливості отримати альтернативні джерела фінансування, а підприємства, в свою чергу, - залучити працівників із відповідними фаховими компетентностями, які дозволяють забезпечити необхідний рівень продуктивності праці та скоротити витрати підприємства на перепідготовку кадрів. Така взаємодія може відбуватися під час реалізації спільних дослідницьких проєктів із подальшою комерціалізацією результатів. Орієнтація на довгострокові та взаємовигідні відносини 3 реальним сектором, що передбачає спільні цілі та цінності (зокрема й соціальної значущості), вимагає 
розробки нових підходів, удосконалення форм i методів управління, впровадження сучасних інструментів ведення бізнесу.

Механізмом, який має об'єднувати зусилля представників бізнесу, науки та суспільства, які по-своєму зацікавлені в проведенні довгострокових науководослідницьких і дослідно-конструкторських робіт, а також організації сумісної діяльності щодо розробки стратегічних планів та їх впровадження, є утворення технологічних платформ.

Технологічна платформа - це комунікаційний інструмент, який: сконцентрований на активізації зусиль зі створення перспективних комерційних технологій, нових продуктів, послуг; спрямований на залучення додаткових ресурсів для проведення досліджень і розробок на основі участі всіх зацікавлених сторін; сприяючий удосконаленню нормативно-правової бази в галузі науково-технологічного й інноваційного розвитку.

Соціальна відповідальність закладу вищої освіти - це додаткові (поза межами освітніх послуг) соціально орієнтовані зобов'язання, що: грунтуються на етичних та правових нормах, сприяючи розвитку внутрішнього та зовнішнього середовища; враховують стратегічні інтереси зацікавлених сторін «освіта-бізнес-суспільство», які, зі свого боку, несуть відповідальність за соціально-економічні наслідки власної діяльності.

Одним з основних засобів формування сучасного ринкового мислення $є$ рівень економічної освіти, який орієнтований на все населення та підкріплений системою інститутів, форм і методів отримання громадянами економічних знань, умінь і навичок, необхідних для їх ефективної соціально-активної діяльності.

Держава, виступаючи носієм специфічного державного інтересу до ринку освітніх послуг, одночасно виступає як розробник і провідник політики в сфері освіти. Адміністративна влада стає адміністративним ресурсом, який дозволяє державі формулювати й успішно задовольняти державні інтереси. Всі учасники ринку зацікавлені в підвищенні конкурентоспроможності своїх партнерів. При цьому потенційні роботодавці очікують конкурентоспроможних працівників і охоче зближуються 3 3ВО, роблячи ставку на рівень їх конкурентоспроможності та на якісних фахівців. Абітурієнти, в свою чергу, також обирають якісні та рейтингові 3ВО, конкурентоспроможність яких визнається академічними колами, бізнес-спільнотою та ін.

У свою чергу, соціально відповідальна вища освіта має забезпечити набуття високого рівня не тільки традиційних професійних компетенцій (навчальна i дослідницька компонента), але й інноваційно орієнтованих $\mathrm{i}$ особливих підприємницьких здібностей.

В основі особливих підприємницьких здібностей особи лежить заповзятливість, яку сучасна наука визначає як важливу особистісну передумову успішної професійної діяльності, оскільки вона виступає характерним способом досягнення конкретних цілей соціально-економічної діяльності через самодостатність в пошуку нестандартних рішень, пов'язаних з господарським ризиком. 
Стабільний розвиток і довгостроковість набутої конкурентної переваги соціально відповідальних організацій забезпечується якістю управління, обізнаністю вищого керівництва та прийняттям соціально-орієнтованих управлінських рішень 3 подальшою імплементацією цих технологій у стратегічний розвиток підприємств. Сприяння активній реалізації перспективних соціальних проєктів, проведення соціально ефективних заходів забезпечують державі розбудову, сприятимуть добробуту та підвищенню якості життя населення України.

Висновки. Виступаючи своєрідним інноваційним вектором розвитку системи вищої освіти соціальна відповідальність, будучи складовою прояву та формування взаємозв'язків зацікавлених сторін («освіта-бізнес-суспільство»), повинна бути інтегрована в усі сфери діяльності організації задля забезпечення iii конкурентоспроможності в довгостроковій стратегічній перспективі.

\section{Перелік посилань}

1. Бібік Н. В. Корпоративна соціальна відповідальність в Україні: сучасний стан та перспективи розвитку. Технічний прогрес $i$ ефективність виробництвва. 2012. № 14. С. 9-16.

2. Березіна О. Ю. Кількісна оцінка соціальної відповідальності корпорацій. Вісник Украӥнської академії банківської справи. 2012. № 1(32). C. $97-101$.

3. Буян О. Я. Підходи до оцінки ефективності корпоративної соціальної відповідальності підприємств в Україні. Вісник Дніпропетровського університету. Серія «Економіка». 2012. Вип. 6 (2). С. 159-165.

4. Зінченко А. Г. Корпоративна соціальна відповідальність 2005-2010 : стан та перспективи розвитку. Київ, 2010. 56 с.

5. Лупак Р. Л. Соціальна відповідальність як складова забезпечення конкурентоспроможності підприємства. Соиіально-трудові відносини : теорія та практика. 2016. № 2. С. 98-103.

6. Власова К. В. Корпоративна соціальна відповідальність - основа інноваційного розвитку підприємств АПК України. Економічний аналіз. Тернопіль. 2018. Том 28. № 3. С. 247-251.

7. Романова О.А. Формирование конкурентных стратегий промышленных предприятий с позиции корпоративной социальной ответственности. Экономические и сочиальные перемены: факты, тенденции, прогноз. 2017. Т. 10. № 6. C. 138-152. DOI: 10.15838/esc.2017.6.54.9.

8. Мазуренко В. П. Сучасна концепція корпоративної соціальної відповідальності у міжнародному бізнесі. Ефективна економіка. 2012. № 6. URL: http://nbuv.gov.ua/UJRN/efek_2012_6_17.

9. Международный стандарт ISO26000:2010, Руководство по социальной ответственности. URL: http://www.iso.org/iso/ru/catalogue detail?csnumber $=42546$.

10. Поляков М. В., Савчук В.С. Класичний університет : еволюція, сучасний стан, перспективи. Київ, 2004. 416 с. 
11. Калінеску Т. В., Калінеску, Г. С. Ліхоносова, Альошкін В. С. Соціальна відповідальність : підручник. Сєвєродонецьк, 2015. 472 с. URL: https://pidruchniki.com/73476/sotsiologiya/sotsialnvidpovidalnistosviti_nauki.

12. Кузьмін О. Є., Пирог О. В., Чернобай Л. І., Романишин С. Б., Вацик Н. О. Соціальна відповідальність : навчальний посібник. Львів, 2016. 328 с.

13. Петухова Е. П. Качество подготовки специалиста в вузе на современном этапе. Материаль Международной научно-практической конферениии „Стратегическое партнерство бизнеса и образования”. Брянск. 2012. C. 116-119.

\section{References}

1. Bibik, N. V. (2012), Corporate Social Responsibility in Ukraine : Current State and Prospects for Development [Korporatyvna sotsialna vidpovidalnist $\mathrm{v}$ Ukraini : suchasnyi stan ta perspektyvy rozvytku], Technical progress and production efficiency, No 14. P. 9-16.

2. Berezina, O. U. (2012), Quantitative assessment of corporate social responsibility [Kilkisna otsinka sotsialnoi vidpovidalnosti korporatsii], Bulletin of the Ukrainian Academy of Banking, No 1(32), P. 97-101.

3. Buyan, O. Ya. (2012), Approaches to the assessment of the effectiveness of corporate social responsibility in Ukraine [Pidkhody do otsinky efektyvnosti korporatyvnoi sotsialnoi vidpovidalnosti pidpryiemstv $\mathrm{v}$ Ukraini], Bulletin of Dnipropetrovsk University. Economy series, No 6 (2), P. 159-165.

4. Zinchenko, A. G. (2010), Corporate Social Responsibility 2005-2010 : Status and Prospects for Development [Korporatyvna sotsialna vidpovidalnist 20052010 : stan ta perspektyvy rozvytku], Kyiv, 56 p.

5. Lupak, R. L. (2016), Social responsibility as a component of ensuring the competitiveness of an enterprise [Sotsialna vidpovidalnist yak skladova zabezpechennia konkurentospromozhnosti pidpryiemstva], Social-labor relations: theory and practice, No. 2, P. 98-103.

6. Vlasova, K. V. (2018), Corporate Social Responsibility - the basis of innovative development of agricultural enterprises of Ukraine [Korporatyvna sotsialna vidpovidalnist - osnova innovatsiinoho rozvytku pidpryiemstv APK Ukrainy], Economic analysis, Ternopil, Volume 28, No. 3, P. 247-251.

7. Romanova, O. A. (2017), Creating Competitive Strategies of Industrial Enterprises from the Standpoint of Corporate Social Responsibility [Formirovanie konkurentnyh strategij promyshlennyh predprijatij s pozicii korporativnoj social'noj otvetstvennosti], Economic and Social Changes: Facts, Trends, Forecast, Vol. 10, No. 6, P. 138-152. DOI : http:doi.org/10.15838/esc.2017.6.54.9.

8. Mazurenko, V.P. (2012), The Modern Concept of Corporate Social Responsibility in International Business [Suchasna kontseptsiia korporatyvnoi sotsialnoi vidpovidalnosti u mizhnarodnomu biznesi], Effective Economy, No. 6, available at : http://nbuv.gov.ua/UJRN/efek_2012_6_17.

9. International Standard ISO 26000: 2010, A Guide to Social Responsibility [Mezhdunarodnyj standart ISO26000:2010, Rukovodstvo po social'noj otvetstvennosti], available at: http://www.iso.org/iso/ru/catalogue_detail?csnumber 
$=42546$.

10. Poliakov, M. V., Savchuk, V. S. (2004), Classic University: evolution, current state, prospects [Klasychnyi universytet : evoliutsiia, suchasnyi stan, perspektyvy], Kiev, 416 p.

11. Kalinesku, T. V., Likhonosova, H. S., Aloshkin, V. S. (2015), Social responsibility [Sotsialna vidpovidalnist], Severodonetsk, 472 p., available at: https://pidruchniki.com/73476/ sotsiologiya / sotsialna vidpovidalnist osviti_nauki.

12. Kuzmin, O. Ye., Pyroh, O. V., Chernobai, L. I., Romanyshyn, S. B., Vatsyk, N. O. (2016), Social responsibility [Sotsialna vidpovidalnist], Lviv, 328 p.

13. Petukhova, E. P. (2012), The quality of training of the specialist in the university at the present stage [Kachestvo podgotovki specialista $v$ vuze na sovremennom jetape. Materialy Mezhdunarodnoj nauchno-prakticheskoj konferencii ,,Strategicheskoe partnerstvo biznesa i obrazovanija], Bryansk, P. 116-119.

\section{РЕФЕРАТИ РЕФЕРАТЫ ABSTRAСТS}

\section{УДК 338.242; JEL Classification: M14}

Кирчата І.М., ШершенюК О.М. ЗАБЕЗПЕЧЕННЯ КОНКУРЕНТО СПРОМОЖНОСТІ ЗАКЛАДУ ВИЩОЇ ОСВІТИ В КОНТЕКСТІ СОЦІАЛЬНОЇ ВІДПОВІДАЛЬНОСТІ

Мета - дослідження сутності, визначення концептуального змісту й обгрунтування необхідності впровадження соціальної відповідальності в систему освітньої діяльності як необхідної передумови забезпечення піi конкурентної стійкості в глобальному освітньому просторі. Методика дослідження. Теоретичною та методологічною основою $є$ основні закони функціонування ринкової економіки, праці провідних вітчизняних і зарубіжних учених-економістів, в яких розглядається соціальна відповідальність у контексті забезпечення конкурентоспроможності закладів вищої освіти через партнерські відносини «освіта-бізнес-суспільство». Використано методи узагальнення та абстрагування; метод аналізу i синтезу. Результати. Соціальна відповідальність в своїй еволюції проходить ряд етапів розвитку та постає інноваційним вектором в діяльності не тільки бізнесу України, але й системи освітнього процесу, зокрема в закладах вищої освіти. Сучасні реалії вимагають посилення інтеграції науки, освіти та інноваційної активності підприємств 3 метою системного впровадження досягнень науки в промисловість, як вагому складову реального сектору економіки, тим самим активізуючи інноваційну діяльність самих підприємств та підсилюючи значущість вищої школи. Соціальна відповідальність закладу вищої освіти - це додаткові (поза межами освітніх послуг) соціально орієнтовані зобов'язання, що: грунтуються на етичних та правових нормах, сприяючи розвитку внутрішнього та зовнішнього середовища; враховують стратегічні інтереси зацікавлених сторін «освіта-бізнес-суспільство», які, зі свого боку, несуть відповідальність за соціально-економічні наслідки власної діяльності. Наукова новизна. В роботі теоретично обгрунтовано доцільність інтеграції соціальної 
відповідальності в систему вищої освіти, як складової прояву та формування взаємозв'язків зацікавлених сторін («освіта-бізнес-суспільство»). Соціальна відповідальність, виступаючи своєрідним інноваційним вектором розвитку системи вищої освіти, має сприяти набуттю високого рівня не тільки традиційних професійних компетенцій (навчальна і дослідницька компонента), але й інноваційно орієнтованих i особливих підприємницьких здібностей здобувачів освіти. Практична значущість полягає в обгрунтовані концептуальних засад щодо цільової спрямованості соціальної відповідальності закладів вищої освіти, які можуть бути використані для розробки та реалізації конкретних стратегічних заходів, спрямованих на формування стійких конкурентних переваг останнього та використання їх як інструмента забезпечення інноваційного та соціально-економічного розвитку партнерських відносин «освіта-бізнес-суспільство».

Ключові слова: вища освіта; соціальна відповідальність; конкурентоспроможність; конкурентна стійкість; соціальні відносини.

\section{УДК 338.242; JEL Classification: M14}

Кирчатая И.Н., Шершенюк Е.Н. ОБЕСПЕЧЕНИЕ КОНКУРЕНТОСПОСОБНОСТИ ОРГАНИЗАЦИИ ВЫСШЕГО ОБРАЗОВАНИЯ В КОНТЕКСТЕ СОЦИАЛЬНОЙ ОТВЕТСТВЕННОСТИ

Цель - исследование сущности, определение концептуального
содержания $\quad$ и обоснование необходимости внедрения социальной ответственности в систему образовательной деятельности как неотъемлемой составляющей обеспечения ее конкурентной устойчивости в глобальном образовательном пространстве. Методика исследования. Теоретической и методологической основой являются основные законы функционирования рыночной экономики, труды ведущих отечественных и зарубежных ученыхэкономистов, в которых рассматривается социальная ответственность в контексте обеспечения конкурентоспособности организации высшего образования через партнерские отношения «образование-бизнес-общество». Pезультаты. Социальная ответственность в своей эволюции прошла ряд этапов развития и предстала инновационным вектором в деятельности не только бизнеса Украины, но и системы образовательного процесса, в том числе в организациях высшего образования. Современные реалии требуют усиления интеграции науки, образования и инновационной активности предприятий с целью системного внедрения достижений науки в промышленность, как весомую составляющую реального сектора экономики, тем самым активизируя инновационную деятельность самих предприятий и усиливая значимость высшей школы. Социальная ответственность организации высшего образования - это дополнительные (вне образовательных услуг) социально ориентированные обязательства, которые: основываются на этических и правовых нормах, способствуя развитию внутренней и внешней среды; учитывают стратегические интересы заинтересованных сторон «образованиебизнес-общество», которые, со своей стороны, несут ответственность за социально-экономические последствия собственной деятельности. Научная 
новизна. В работе теоретически обоснована целесообразность интеграции социальной ответственности в систему высшего образования, как составляющей проявления и формирования взаимосвязей заинтересованных сторон («образование-бизнес-общество»). Социальная ответственность, выступая своеобразным инновационным вектором развития системы высшего образования, должна способствовать обретению высокого уровня не только традиционных профессиональных компетенций (учебная и исследовательская компонента), но и инновационно ориентированных и особенных предпринимательских способностей соискателей образования. Практическая значимость заключается в обосновании концептуальных основ целевой направленности социальной ответственности организаций высшего образования, которые могут быть использованы для разработки и реализации стратегических мероприятий, направленных на формирование устойчивых конкурентных преимуществ и использование их как инструмента обеспечения инновационного и социально-экономического развития партнерских отношений «образование-бизнес-общество».

Ключевые слова: высшее образование; социальная ответственность; конкурентоспособность; конкурентная устойчивость; социальные отношения.

\section{UDC 338.242; JEL Classification: M14}

\section{Kyrchata I.M., Shershenyuk O.M. PROVIDING THE COMPETITIVENESS OF THE HIGHER EDUCATION INSTITUTE IN THE CONTEXT OF SOCIAL RESPONSIBILITY}

Purpose - to study the essence, determine the conceptual content and justify the need to introduce social responsibility in the educational system as a necessary prerequisite for its competitive stability in the global educational space. Methodology of research. The theoretical and methodological basis are the basic laws of functioning of market economy, works of leading domestic and foreign scientistseconomists, in which the social responsibility is considered in the context of ensuring the competitiveness of higher education institutions through partnerships "educationbusiness-society". Methods of generalization and abstraction were used. Method of analysis and synthesis was used. Findings. During its evolution the social responsibility goes through a number of stages of development and emerges as an innovative vector in the activity not only of Ukraine's business, but also of the educational process, in particular in institutions of higher education. The social responsibility of a higher education institution is an additional (outside of educational services) socially-oriented commitments that: are based on ethical and legal standards, which contribute to the development of the internal and external environment; take into account the strategic interests of the "education-businesssociety" stakeholders, which, in turn, are responsible for the socio-economic consequences of their activity. Originality. In this paper the feasibility of integrating social responsibility into a system of higher education, as a component of manifestation and formation of stakeholder relations ("education-business-society") is substantiated theoretically. Acting as a kind of innovative vector for the development of higher education the social responsibility should contribute to the 
acquisition of a high level of not only traditional professional competences (educational and research component), but also innovatively oriented and special entrepreneurial abilities of applicants. The practical relevance lies in the substantiated conceptual framework for the goal of social responsibility of higher education institutions, which can be used to develop and implement of specific strategic measures which are aimed to generate sustainable competitive advantages of the latter and use them as a tool for ensuring the innovative and socio-economic development of partnerships "education-business-society" relations.

Key words: higher education; social responsibility; competitiveness; competitive stability; social relations.

\section{Відомості про авторів / Сведения об авторах / About the Authors}

Кирчата Ірина Миколаївна - кандидат економічних наук, доцент, Харківський національний автомобільно-дорожній університет, доцент кафедри економіки i підприємництва, м. Харків, Україна; e-mail: kirchatayairina@gmail.com; ORCID: https://orcid.org/0000-0002-0270-1586. Моб. (050)669-00-96.

Кирчатая Ирина Николаевна - кандидат экономических наук, доцент, Харьковский национальный автомобильно-дорожный университет, доцент кафедры экономики и предпринимательства, г. Харьков, Украина.

Kyrchata Iryna - PhD in Economics, Associate Professor, Kharkiv National Automobile and Highway University, Associate Professor of Department of Economics and Entrepreneurship, Kharkiv, Ukraine.

Шершенюк Олена Миколаївна - кандидат економічних наук, доцент, Харківський національний автомобільно-дорожній університет, доцент кафедри економіки і підприємництва, м. Харків, Україна; e-mail: sheralyona@gmail.com; ORCID: https://orcid.org/0000-0002-9959-2725. Моб. (050)151-30-09.

Шершенюк Елена Николаевна - кандидат экономических наук, доцент, Харьковский национальный автомобильно-дорожный университет, доцент кафедры экономики и предпринимательства, г. Харьков, Украина.

Shershenyuk Elena - PhD in Economics, Associate Professor, Kharkiv National Automobile and Highway University, Associate Professor of Department of Economics and Entrepreneurship, Kharkiv, Ukraine. 